\title{
Catalytically active palladium nanoparticles embedded in an organic-inorganic fluorinated hybrid material
}

\author{
Sandra Niembro, Alexandr Shafir,* and Adelina Vallribera* \\ Department of Chemistry, Universitat Autònoma de Barcelona, 08193 Cerdanyola del Vallès, \\ Barcelona, Spain \\ E-mail: adelina.vallribera@uab.es
}

\begin{abstract}
Dedicated to Professor Benito Alcaide (Universidad Complutense de Madrid) on the occasion of his $60^{\text {th }}$ anniversary
\end{abstract}

\begin{abstract}
Palladium nanoparticles were supported on a fluorous organic-inorganic hybrid material prepared by the sol-gel process without TEOS. Recycling studies on the Heck coupling reaction have shown that the catalyst can be readily recovered and reused.
\end{abstract}

Keywords: Palladium, nanoparticles, Heck, recycling, fluorous, sol-gel

\section{Introduction}

A large body of work has been dedicated to the use of palladium nanoparticles (PdNPs) as catalysts for the formation of $\mathrm{C}-\mathrm{C}$ bonds. ${ }^{1,2}$ A major effort has been dedicated to supporting PdNPs on a variety of materials ${ }^{3}$ in order to facilitate the separation, recovery and reuse of expensive palladium catalysts. Our group in particular has contributed in this work with the preparation of nanosized metallic palladium particles embedded in silica and carbon aerogels. ${ }^{4}$

We have previously reported that heavily fluorinated star-shaped compounds (A, Figure 1) favor the formation of palladium nanoparticles (PdNPs-A) that were catalytically active in C-C bond forming processes. ${ }^{5}$ Although in principle heavily fluorinated compounds do not seem ideal stabilizers for nanoparticles, we demonstrated that some compounds can indeed be used with success as a protecting shield for nanoparticles. Furthermore, we demonstrated that PdNPs-A could be embedded within a fluorous silica gel matrix and that this material showed promise as a catalyst for the Heck reaction. However, subsequent analysis of the reaction mixture revealed some leaching of both the palladium and the fluorous stabilizer. ${ }^{6}$ Most recently, we prepared a more robust hybrid material PdNPs-B with the stabilizer linked covalently to the silica gel matrix. ${ }^{7}$ In this case, the matrix was prepared through sol-gel condensation between a 
monosilylated fluorous precursor and a large excess of tetraethoxysilane (TEOS). The resulting material acts as an efficient stabilizer of catalytically active PdNPs (diameter $4 \pm 1 \mathrm{~nm}$ ) (PdNPsB, Figure 1). Despite these promising results, the material was found to contain only $3.95 \%$ of palladium. With the aim of obtaining new catalytically active materials that could support larger quantities of highly dispersed nanosized palladium particles, we decided to prepare an organicinorganic polymer based on the sol-gel process of the bis-silylated compound $\mathbf{3 b}$ (Scheme 1). In this case, the presence of not one, but two silyl groups would allow for the synthesis of a stable sol-gel matrix without the need for addition of TEOS. The idea was that the quantity of embedded palladium would be controlled by the amount of the organic part in the hybrid material.

a)

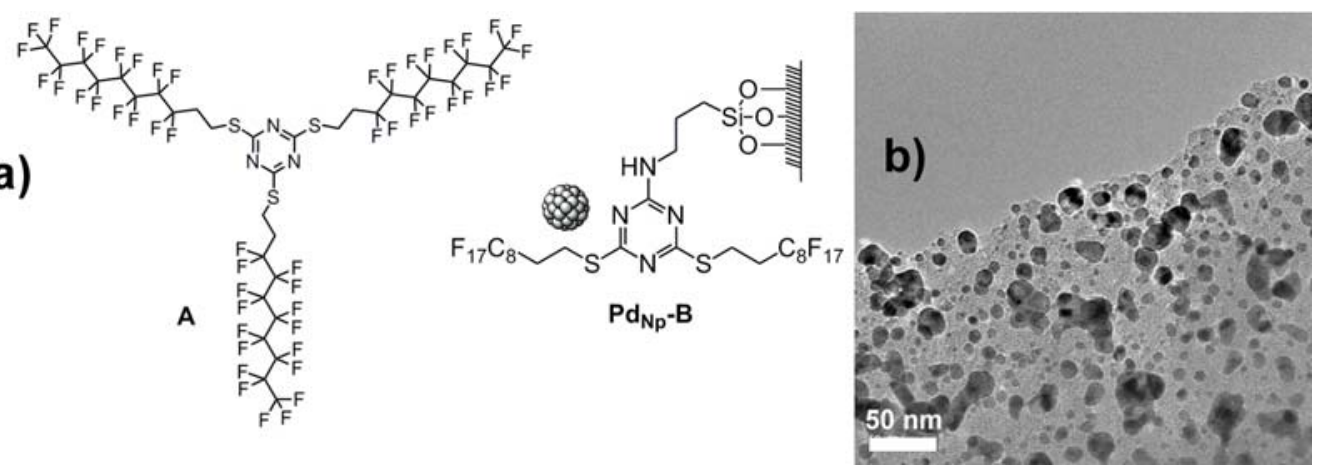

Figure 1. (a) Star-shaped stabilizer A and material PdNPs-B. (b) HRTEM image of PdNPs-B.

\section{Results and Discussion}

Our objective was to obtain an organic-inorganic hybrid material with a regular and stoichiometric distribution of the highly fluorinated organic moieties throughout the silicate network, capable of supporting metallic nanoparticles. Therefore, we proposed the synthesis of a precursor containing two trialkoxysilane groups that could condense through a sol-gel process without the presence of the TEOS. ${ }^{8}$ The idea is that increasing the number of perfluorinated chains the percentage of nanosized palladium stabilized by the material will be higher.

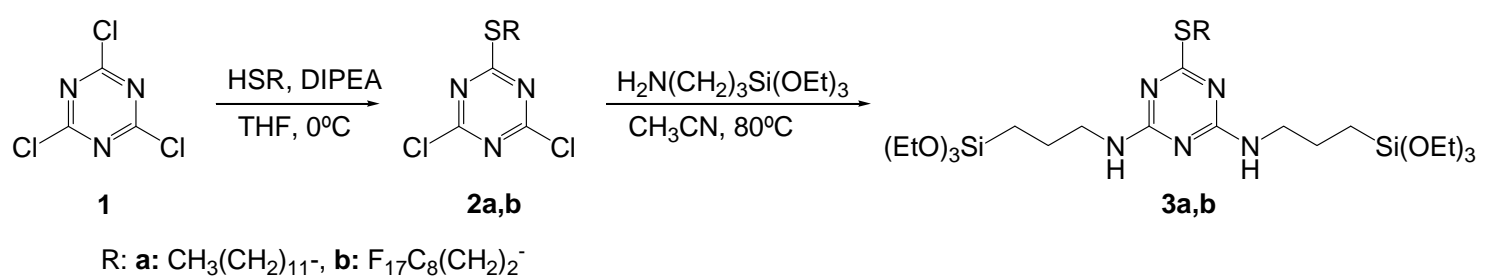

Scheme 1. Synthesis of bis-silylated compounds 3a,b. 
The preparation of the bis-silylated monomer was based on successive substitutions of 2,4,6trichloro-1,3,5-triazine. The methodology was initially optimized using the non-fluorinated dodecanethiol. First, selective substitution of a single chloride was achieved trough the reaction of 1 with the dodecanethiol in THF at $0{ }^{\circ} \mathrm{C}$ in the presence of di-isopropyl ethylamine (DIPEA). Thus, after 30 minutes, the product 2a was obtained in quantitative yield, with longer reaction times leading to the formation of some of the bis-substituted product. The remaining chlorides were substituted by the bifunctional 3-(triethoxysilyl)propan-1-amine in $\mathrm{CH}_{3} \mathrm{CN}$ at $80{ }^{\circ} \mathrm{C}$ using DIPEA as a base, giving a 98\% yield of the trisubstituted 3a. The ${ }^{1} \mathrm{H}$ NMR characterization of this product was complicated by the restricted rotation around $\mathrm{C}-\mathrm{N}$ bonds and the presence of several interconverting tautomers at $25{ }^{\circ} \mathrm{C}$ (Figure 2a). The spectrum, therefore, was recorded at $80^{\circ} \mathrm{C}$, allowing for the observation of the much simplified average structure (Figure $2 \mathrm{~b}$ ). ${ }^{9}$

With the conditions established, we repeated the steps with $1 \mathrm{H}, 1 \mathrm{H}, 2 \mathrm{H}, 2 \mathrm{H}$ perfluorodecanethiol, giving a quantitative yield of the monosubstituted product $\mathbf{2 b}$ and, subsequently, a 93\% yield of the desired fluorinated monomer $3 \mathbf{b}$ (Scheme 1).

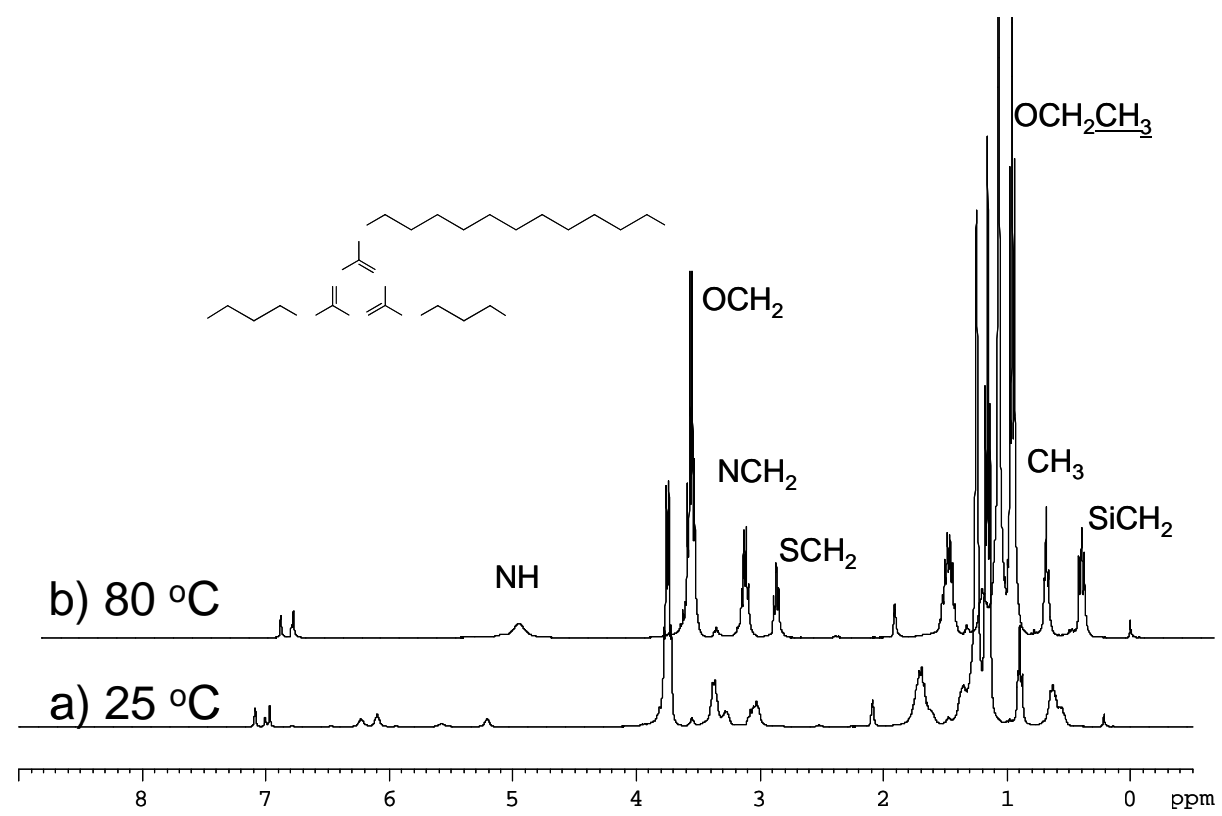

Figure 2. ${ }^{1} \mathrm{H}$ NMR of $3 a$ at $25^{\circ} \mathrm{C}$ and at $80{ }^{\circ} \mathrm{C}$.

Having obtained the polyfluorinated monomer, $3 \mathbf{b}$, we explored the conditions necessary to carry out the sol-gel process. The standard conditions based on a mixture of ethanol, water and ammonium fluoride as catalyst led, upon the addition of water, to the rapid precipitation of the monomer. Similarly, attempted use of the formic acid led to the formation of a heterogeneous mixture. $^{10}$ 

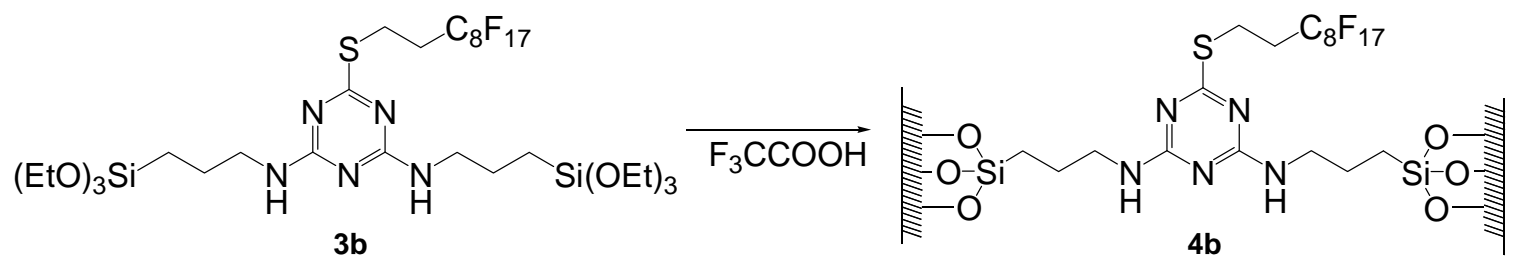

Scheme 2. Synthesis of hybrid material $\mathbf{4 b}$.

Finally, a homogeneous gel was formed using trifluoroacetic acid as a gelling agent (Scheme 2) The use of this acid as both solvent and catalyst in sol-gel processes has been described by Sharp and co-workers ${ }^{11}$ and has been successfully applied in our own work. ${ }^{7}$ The final product was characterized by the solid state ${ }^{29} \mathrm{Si}$ and ${ }^{13} \mathrm{C}$ NMR (Figure 3 ) and by the elemental analysis. In the ${ }^{29} \mathrm{Si}$ NMR spectrum only the $\mathrm{T}$ units at around -56 to $-70 \mathrm{ppm}$ are observed, indicating the hydrolysis-condensation of $\mathbf{3 b}$. In the solid state ${ }^{13} \mathrm{C}$ NMR spectrum we were able to assign the chemical shifts of the organic part. The spectrum shows the following carbon resonances: 178.3155.5 (1,3,5-triazina ring), 118.7-111.6 (polyfluorinated chain), $44.1\left(\mathrm{CH}_{2} \mathrm{NH}\right), 32.6\left(\mathrm{SCH}_{2}\right)$, $23.1\left(\mathrm{CH}_{2} \mathrm{CH}_{2} \mathrm{Si}\right)$ and $10.4(\mathrm{CSi})$ ppm, which confirms the presence the of the ligand covalently bonded to silica; elemental analysis is consistent with the formation of the desired material.

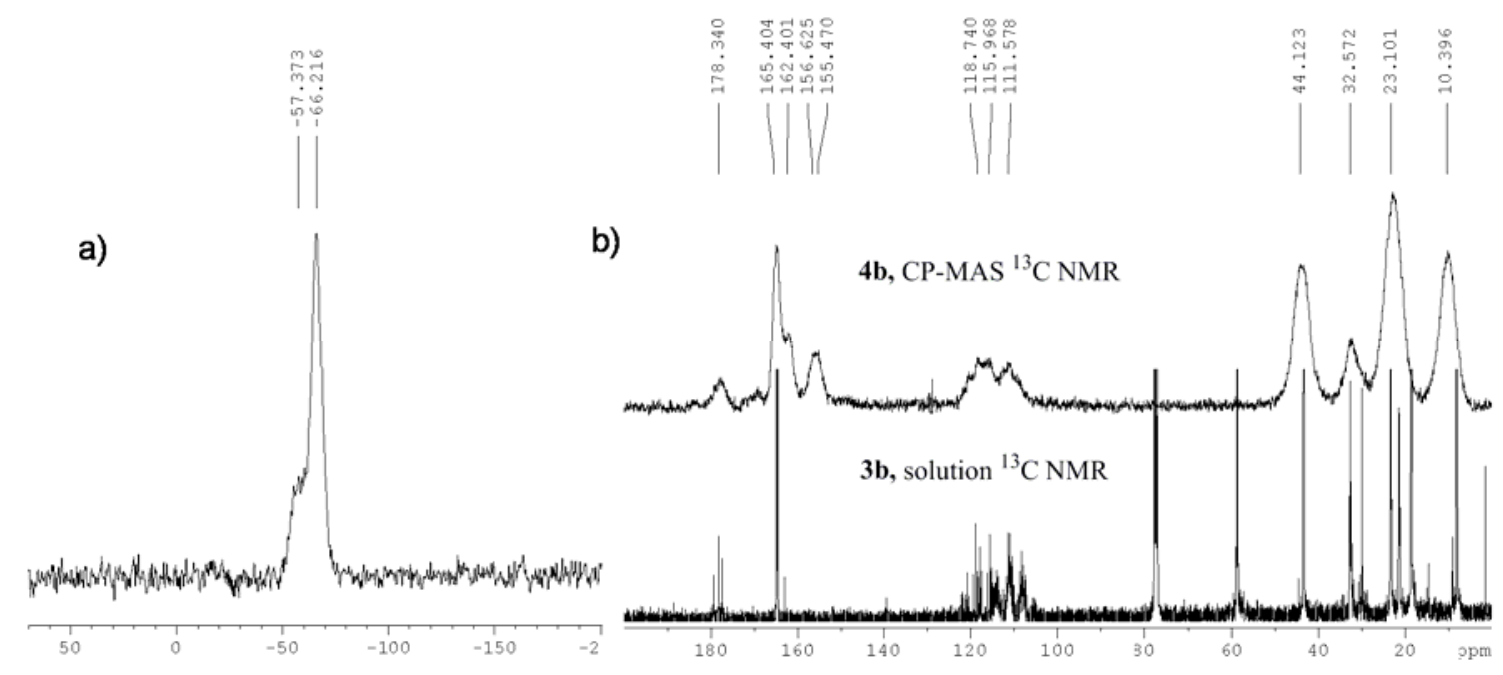

Figure 3. (a) solid state ${ }^{29} \mathrm{Si}$ NMR and (b) CP-MAS solid state ${ }^{13} \mathrm{C}$ NMR of $\mathbf{4 b}$ and ${ }^{13} \mathrm{C}$ NMR of 3b.

Palladium nanoparticles were then prepared by the reduction of $\mathrm{Na}_{2} \mathrm{Pd}_{2} \mathrm{Cl}_{6}$ (prepared from palladium (II) chloride and sodium chloride) with methanol at $60{ }^{\circ} \mathrm{C}$ in the presence of stabilizer $\mathbf{4 b}$, affording, after the addition of $\mathrm{NaOAc}$ to induce precipitation, a black solid corresponding to PdNPs-4b.(Scheme 3). 


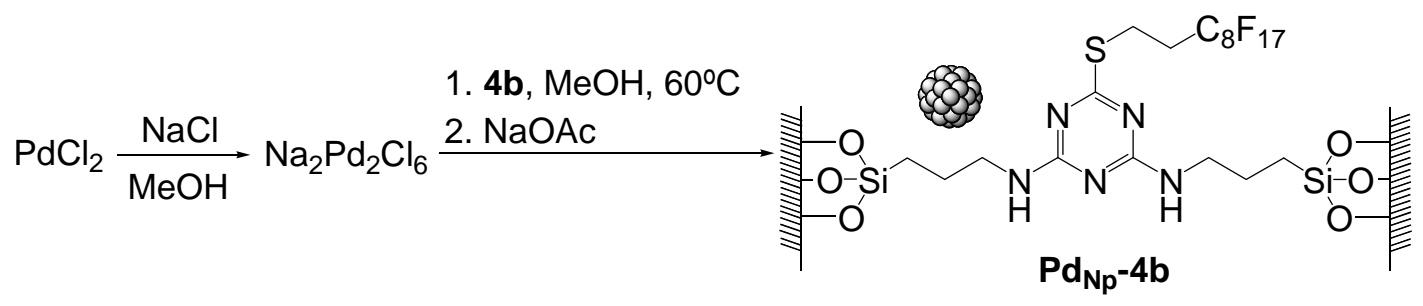

Scheme 3. Synthesis of palladium(0) nanoparticles.

Transmission electron microscopy (TEM) confirmed the presence of metal nanoparticles with an average size of $4 \mathrm{~nm}$ (Figure 4) and electron diffraction confirmed the existence of the face-centered cubic palladium(0). The palladium content of $12.50 \%$ determined by ICP was significantly higher than the $4 \%$ incorporation achieved using TEOS at the sol-gel stage. With respect to the phenomenon of the stabilization we propose that Nps are entrapped in the solid network, with the initial interactions probably taking place through the sulfur and nitrogen coordinating atoms. Upon reduction, the presence of long perfluorinated chains prevents the agglomeration of the nanoparticles.
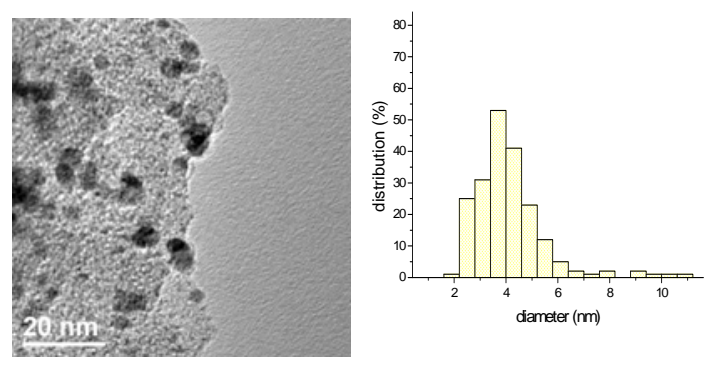

Figure 4. TEM image and particle size distribution histogram of PdNPs-4b.

The resulting material was tested as catalysts in the $\mathrm{Heck}^{12}$ reaction of iodobenzene with butyl acrylate in $\mathrm{CH}_{3} \mathrm{CN}$ at $130{ }^{\circ} \mathrm{C}$ using tributylamine as a base with the amount of catalyst corresponding to $2 \%$ molar palladium. The reaction was complete in $24 \mathrm{~h}$ and the catalyst could be recovered and reused for six consecutive runs without appreciable loss of activity (Scheme 4).

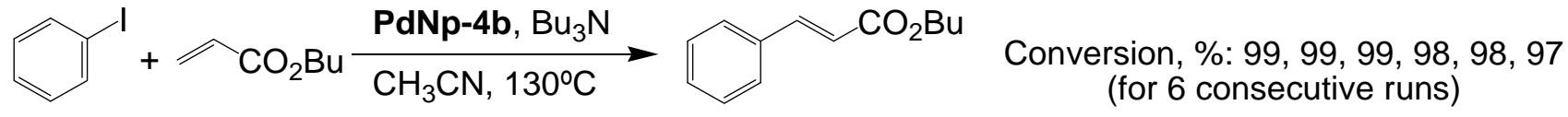

Scheme 4. Heck reaction catalyzed by $\mathbf{P d}_{\mathrm{Np}}-\mathbf{4 b}$. 


\section{Conclusions}

A new fluorous organic-inorganic hybrid material has been prepared by a tetraethoxysilane-free sol-gel process. The material was used as a stabilizer in the formation of palladium nanoparticles, giving levels of palladium incorporation superior to those obtained with the TEOS-based material. We demonstrated that the phenomenon of the stabilization of the nanoparticles is not due exclusively to entrapment of metallic particles on the polymeric network, as the efficiency of the synthesis was found to directly depend on the number of the long perfluorinated alkyl chains. Moreover this allows carrying out the catalytic Heck reactions with a lower quantity of material.

\section{Experimental Section}

General Procedures. All reagents were purchased from commercial sources and were used as received. Anhydrous THF was obtained by distilling from sodium metal/benzophenone, and $\mathrm{CH}_{3} \mathrm{CN}$ was distilled from $\mathrm{P}_{2} \mathrm{O}_{5}$. Experiments requiring nitrogen atmosphere were carried out using standard Schlenk line techniques. All NMR measurements were carried out at the Servei de Ressonància Magnètica Nuclear at the Universitat Autònoma de Barcelona. Routine ${ }^{1} \mathrm{H}$ and ${ }^{13} \mathrm{C}$ NMR were recorded on Bruker AC250 $\left(250 \mathrm{MHz}\right.$ for $\left.{ }^{1} \mathrm{H}\right)$ and Avance360 $\left(360 \mathrm{MHz}\right.$ for $\left.{ }^{1} \mathrm{H}\right)$ instruments. Solid state Cross Polarization / Magic Angle Spinning (CP MAS) NMR spectra were recorded using a Bruker AvanceII $400 \mathrm{MHz}$ WB instrument. Infrared spectra were recorded using a Bruker Tensor 27 instrument equipped with an ATR Golden Gate cell and a diamond window. Routine $\mathrm{CHN}$ elemental analyses were performed at the Servei de Microanàlisi del CSIC de Barcelona. ICP measurements of palladium contents were carried out at the Serveis Cientificotècnics of the Universitat de Barcelona. HR-MS measurements were performed at the Servei d'Anàlisi Química of the Universitat Autònoma de Barcelona. Melting points were determined using a Reichert brand melting point apparatus. Transmission electron microscopy (TEM) analyses were performed in the Servei de Microscòpia of the Universitat Autònoma de Barcelona, using a JEOL JEM-2010 model at 200kV. For the TEM measurement, the nanoparticulate material was subjected to sonication in perfluorooctyl bromide for several minutes. A drop of this finely dispersed suspension was placed on a specially produced structureless carbon support film having a thickness of 4-6 nm and dried before observation.

2,4-dichloro-6-(dodecylthio)-1,3,5-triazine (2a). A $250 \mathrm{~mL}$ Schlenk tube charged with a magnetic stirbar and 2,4,6-trichloro-1,3,5-triazine $1(0.50 \mathrm{~g}, 2.71 \mathrm{mmol}, 1.25$ equiv) was evacuated and refilled with nitrogen. After the addition of THF (anhydrous, $50 \mathrm{~mL}$ ) and $\mathrm{N}, \mathrm{N}$ diisopropylethylamine $(0.57 \mathrm{~mL}, 3.57 \mathrm{mmol})$, the flask was fitted with an addition funnel and cooled to $0^{\circ} \mathrm{C}$. Separately, a solution of $n$-dodecanethiol $(0.52 \mathrm{~mL}, 2.17 \mathrm{mmols})$ in THF $(30 \mathrm{~mL})$ was prepared and transferred to the funnel. This solution was added dropwise, the reaction mixture was allowed to stir for $30 \mathrm{~min}$ at $0{ }^{\circ} \mathrm{C}$, and then was allowed to warm to room 
temperature. At this point, the solvent was removed and the crude mixture was passed through a short column of silica gel, eluting with a 98: 2 hexane: ethyl acetate mixture. Removal of the solvent afforded $0.76 \mathrm{~g}(2.16 \mathrm{mmol}$, quantitative yield $)$ of the desired product as a white solid. Mp: $25-27{ }^{\circ} \mathrm{C}$ (lit. $\left.{ }^{13} \mathrm{mp} 23-26{ }^{\circ} \mathrm{C}\right) .{ }^{1} \mathrm{H}$ NMR $\left(\mathrm{CDCl}_{3}, 250 \mathrm{MHz}\right): \delta 3.15$ (t, $J=7.3 \mathrm{~Hz}, 2 \mathrm{H}, \mathrm{SCH}_{2}$ ), $1.70(\mathrm{~m}, 2 \mathrm{H}), 1.38(\mathrm{~m}, 2 \mathrm{H}), 1.23(\mathrm{~m}, 16 \mathrm{H}), 0.84\left(\mathrm{t}, J=6.5 \mathrm{~Hz}, 3 \mathrm{H}, \mathrm{CH}_{3}\right) \mathrm{ppm} .{ }^{13} \mathrm{C} \mathrm{NMR}\left(\mathrm{CDCl}_{3}\right.$, $62.5 \mathrm{MHz}): \delta 186.9\left(\mathrm{CSCH}_{2}\right), 170.3(\mathrm{CCl}), 32.2,31.5,29.9,29.8,29.7,29.6,29.2,28.9,28.6$, 22.9, 14.4 ppm. IR (ATR, $\mathrm{cm}^{-1}$ ): 2922, 2852, 1510, 1239, 842.

2,4-dichloro-6-(1H,1H,2H,2H-perfluorodecylthio)-1,3,5-triazine (2b). A $250 \mathrm{~mL}$ Schlenk tube charged with a magnetic stirbar and 2,4,6-trichloro-1,3,5-triazine $(0.40 \mathrm{~g}, 2.17 \mathrm{mmol}, 1.25$ equiv) was evacuated and refilled with nitrogen. After the addition of THF (anhydrous, $70 \mathrm{~mL}$ ) and $N, N$-diisopropylethylamine $(0.45 \mathrm{~mL}, 2.58 \mathrm{mmol})$, the flask was fitted with an addition funnel and cooled to $0{ }^{\circ} \mathrm{C}$. Separately, a solution of $1 \mathrm{H}, 1 \mathrm{H}, 2 \mathrm{H}, 2 \mathrm{H}$-perfluorodecanethiol $(0.50 \mathrm{~mL}, 1.73 \mathrm{mmols})$ in THF $(30 \mathrm{~mL})$ was prepared and transferred to the funnel. This solution was added dropwise, the reaction mixture was allowed to stir for $30 \mathrm{~min}$ at $0{ }^{\circ} \mathrm{C}$, and then was allowed to warm to room temperature. At this point, the solvent was removed and the crude reaction was passed through a short column of silica gel, eluting with a 98:2 hexane: ethyl acetate mixture. Removal of the solvent afforded $1.07 \mathrm{~g}(1.70 \mathrm{mmol}$, quantitative yield) of the desired product as a white solid. Mp: $60-62{ }^{\circ} \mathrm{C} ;{ }^{1} \mathrm{H}$ NMR $\left(\mathrm{CDCl}_{3}, 360 \mathrm{MHz}\right): \delta 3.42(\mathrm{~m}, 2 \mathrm{H}$, $\left.\mathrm{SCH}_{2}\right), 2.62\left(\mathrm{~m}, 2 \mathrm{H}, \mathrm{CH}_{2} \mathrm{CF}_{2}\right)$ ppm. ${ }^{13} \mathrm{C} \mathrm{NMR}\left(\mathrm{CDCl}_{3}, 62.5 \mathrm{MHz}\right): \delta 185.2\left(\mathrm{CSCH}_{2}\right), 170.8$ (CCl), $31.2(\mathrm{t}, J=22.0 \mathrm{~Hz}), 22.5 \mathrm{ppm}$. IR (ATR, $\mathrm{cm}^{-1}$ ): 1512, 1470, 1197, 1144, 1115, 1095, 845. 6-(dodecylthio)- $N^{2}, N^{4}$-bis(3-(triethoxysilyl)propyl)-1,3,5-triazine-2,4-diamine (3a). A $100 \mathrm{~mL}$ Schlenk tube was charged with $2 \mathrm{a}(0.46 \mathrm{~g}, 1.30 \mathrm{mmol})$ and the contents were flushed thoroughly with nitrogen. $\mathrm{CH}_{3} \mathrm{CN}$ (anhydrous, $12 \mathrm{~mL}$ ) and $N, N$-diisopropylethylamine $(0.76 \mathrm{~mL}$, $3.25 \mathrm{mmol}$ ) were added, followed by 3-(triethoxysilyl)propan-1-amine $(0.79 \mathrm{~mL}, 4.54 \mathrm{mmol})$. The mixture was heated at $80{ }^{\circ} \mathrm{C}$ for $48 \mathrm{~h}$. After cooling to room temperature, solvent was removed, and the residue was taken up in diethyl ether. The solvent was evaporated, affording $0.91 \mathrm{~g}(98 \%)$ of the desired product as an orange oil. ${ }^{1} \mathrm{H}$ NMR (toluene- $d_{8}, 80{ }^{\circ} \mathrm{C}, 360 \mathrm{MHz}$,): $\delta$ $5.13(\mathrm{~m}, 2 \mathrm{H}, \mathrm{NH}), 3.74\left(\mathrm{q}, J=7.0 \mathrm{~Hz}, 12 \mathrm{H}, \mathrm{OCH}_{2}\right), 3.30\left(\mathrm{q}, J=6.6 \mathrm{~Hz}, 4 \mathrm{H}, \mathrm{NHCH}_{2}\right), 3.05(\mathrm{t}$, $\left.J=7.2,2 \mathrm{H}, \mathrm{SCH}_{2}\right), 1.66(\mathrm{~m}, 6 \mathrm{H}), 1.36(\mathrm{~m}, 2 \mathrm{H}), 1.25(\mathrm{~m}, 16 \mathrm{H}), 1.14(\mathrm{t}, J=7.0 \mathrm{~Hz}, 18 \mathrm{H}$, $\mathrm{OCH}_{2} \mathrm{CH}_{3}$ ), 0.86 (t, J=6.5 HZ, 3H, $\mathrm{CH}_{3}$ ), 0.58 (t, J=8.1 Hz, 4H, $\mathrm{SiCH}_{2}$ ) ppm. IR (ATR, $\mathrm{cm}^{-1}$ ): 2924, 1545, 1104, 1079, 632. HR-MS (ESI): calculated for [M+ H] $]^{+}: 720.4580$, found: 720.4602 . 6-(1H,1H,2H,2H-perfluorodecylthio)- $N^{2}, N^{4}$-bis(3-(triethoxysilyl)propyl)-1,3,5-triazine-2,4diamine (3b). A $100 \mathrm{~mL}$ Schlenk tube was charged with $2 \mathbf{b}(0.60 \mathrm{~g}, 0.96 \mathrm{mmol})$ and the contents were flushed thoroughly with nitrogen. $\mathrm{CH}_{3} \mathrm{CN}$ (anhydrous, $24 \mathrm{~mL}$ ) and $N, N$ diisopropylethylamine $(0.60 \mathrm{~mL}, 3.44 \mathrm{mmol})$ were added, followed by 3-(triethoxysilyl)propan1 -amine $(0.56 \mathrm{~mL}, 2.39 \mathrm{mmol})$. The mixture was heated at $80^{\circ} \mathrm{C}$ for $48 \mathrm{~h}$. After cooling to room temperature, solvent was removed. $\mathrm{CH}_{2} \mathrm{Cl}_{2}$ was added and the organic solution was washed with water. The organic layer was dried and the solvent was evaporated, affording $0.89 \mathrm{~g}(93 \%)$ of the desired product as an orange oil. ${ }^{1} \mathrm{H}$ NMR (toluene- $d_{8}, 80{ }^{\circ} \mathrm{C}, 360 \mathrm{MHz}$,): $\delta 5.05(\mathrm{~m}, 2 \mathrm{H}, \mathrm{NH}$ ), 3.77 (q, J=7.0 Hz, 12H, $\left.\mathrm{OCH}_{2}\right), 3.31$ (q, J=6.5 Hz, 4H, $\left.\mathrm{NHCH}_{2}\right), 3.31$ (m, 2H, $\left.\mathrm{SCH}_{2}\right), 2.49$ (m, 
$\left.2 \mathrm{H}, \mathrm{CH}_{2} \mathrm{CF}_{2}\right), 1.66(\mathrm{~m}, 4 \mathrm{H}), 1.17$ (t, J=7.0 Hz, 18H, $\left.\mathrm{OCH}_{2} \mathrm{CH}_{3}\right), 0.60$ (t, J=7.9 Hz, 4H, $\left.\mathrm{SiCH}_{2}\right)$ ppm. IR (ATR, $\mathrm{cm}^{-1}$ ): 2974, 2928, 2885, 1548, 1203, 1102. HR-MS (ESI): calculated for [M+ $\mathrm{H}]^{+}:$998.2665, found: 998.2698 .

Preparation of $\mathbf{4 b}$. Trifluoroacetic acid $(0.25 \mathrm{~mL})$ was added to a vial containing the fluorinated monomer $3 \mathbf{b}(0.50 \mathrm{~g}, 0.60 \mathrm{mmols})$. The mixture was agitated manually until a homogeneous mixture was achieved and was left undisturbed at room temperature. After 30 minutes, gelation was observed. After a 5 day ageing period, the resulting gel was crushed to a fine powder and washed successively three timers with each of the following solvents: $\mathrm{CH}_{2} \mathrm{Cl}_{2}$, water, $\mathrm{EtOH}$ and $\mathrm{Et}_{2} \mathrm{O}$. The product was dried overnight in a vacuum oven at $80{ }^{\circ} \mathrm{C}$ affordind $396 \mathrm{mg}$ of a lightorange solid. Anal. Found: C, 28.95 and $29.96 \%$; H, 2.26 and $2.33 \%$; N, 8.20 and $8.29 \%$. ${ }^{13} \mathrm{C}$ NMR (100.62 MHz, CP-MAS): $\delta$ 178.3, 165.2, 156.80, 118.7-111.6, 44.1, 32.6, 23.1, 10.4 ppm. ${ }^{29} \mathrm{Si}-\mathrm{NMR}$ (79.5 MHz, CP-MAS): $\delta$-57.4, -66.2 ppm.

Preparation of nanoparticles PdNPs -4b. A $5 \mathrm{~mL}$ round-bottom flask was charged with $\mathrm{PdCl}_{2}$ (34.1 mg, $0.19 \mathrm{mmol}), \mathrm{NaCl}(11.0 \mathrm{mg}, 0.19 \mathrm{mmol})$ and $\mathrm{MeOH}(1 \mathrm{~mL})$. The mixture was left stirring at room temperature for $24 \mathrm{~h}$. the solution was then filtered through a plug of glass wool and the filtrate was diluted with additional $18 \mathrm{~mL}$ of $\mathrm{MeOH}$. Material $3 \mathbf{b}$ (150.2 $\mathrm{mg}$ ) was added, and the mixture was heated to $60{ }^{\circ} \mathrm{C}$ for $24 \mathrm{~h}$. Sodium acetate was added (111 $\left.\mathrm{mg}, 1.35 \mathrm{mmol}\right)$ and the reaction mixture was left cooling to room temperature for 90 minutes. The resulting precipitate was separated by centrifugation, and was washed successively with $\mathrm{MeOH}$, water and acetone, giving the product as a black solid. Pd analysis (ICP): 12.5\%. Average particle diameter: $4 \pm 1 \mathrm{~nm}$ (HRTEM).

Heck reaction. A screw-cap test tube was charged with a magnetic stirbar, PdNPs-4b (4.6 mg, $0.005 \mathrm{mmol} \mathrm{Pd})$, iodobenzene $(0.030 \mathrm{~mL}, 0.27 \mathrm{mmol})$, butyl acrylate $(0.058 \mathrm{~mL}, 0.40 \mathrm{mmol})$, $\mathrm{Bu}_{3} \mathrm{~N}(0.128 \mathrm{~mL}, 0.54 \mathrm{mmol})$ and $3 \mathrm{~mL}$ of $\mathrm{CH}_{3} \mathrm{CN}$. Undecane $(0.057 \mathrm{~mL}, 0.27 \mathrm{mmol})$ was added as an internal standard. The mixture was heated at $130{ }^{\circ} \mathrm{C}$ for $24 \mathrm{~h}$. Conversion was then determined by gas chromatography. Catalyst was separated by filtration, washed with $\mathrm{CH}_{3} \mathrm{CN}$ and dried in vacuum. The material could be reused for the following run.

\section{Acknowledgements}

Financial support from Ministerio de Ciencia e Innovación of Spain (Projects CTQ2008-05409C02-01 and CTQ2005-04968-C02-01 and Consolider Ingenio 2010 (CSD2007-00006)) and DURSI-Generalitat de Catalunya (SGR 2005-00305) are gratefully acknowledged. A.S. has been supported through a Ramon y Cajal contract from the Ministerio de Educación y Ciencia of Spain. S.N. acknowledges MEC for a predoctoral fellowship. 


\section{References}

1. Djakovitch, L.; Koehler, K.; de Vries, J.G. The role of palladium nanoparticles as catalysts for carbon-carbon coupling reactions in Nanoparticles and Catalysis, Astruc, D. Ed.; WileyVCH: Weinheim, 2008.

2. For recent reviews of the use of nanosize palladium catalysts in $\mathrm{C}-\mathrm{C}$ bond forming reactions, see: (a) Moreno-Mañas, M.; Pleixats, R. Acc. Chem. Res. 2003, 36, 638. (b) Tsuji, Y.; Fujihara, T. Inorg. Chem. 2007, 46, 1895. (c) Astruc, D. Inorg. Chem. 2007, 46, 1884. (d) Migowski, P.; Dupont, J. Chem. Eur. J. 2007, 13, 32. (d) Pd nanoparticles Pleixats, R.; Vallribera, A.; Sebastián, R. M. Pd nanoparticles in Electronic Encyclopedia of Reagents for Organic Synthesis; in DOI: 10.1002/047084289X.rn00337u.pub2, 2008.

3. For some recent examples of supported PdNPs see: (a) Evangelista, C.; Panziera, N.; Pertici, P.; Vitulli, G.; Salvadori, P.; Battocchio, C.; Polzonetti, G. J. Cat. 2009, 262, 287. (b) Zhu, J.; Zhou, J.; Zhao, T; Zhou, X.; Chen, D. Yuan, W. Appl. Catal. A-Gen. 2009, 352, 243. (c) Beletskaya, I. P.; Kashin, A. N.; Litvinov, A. E.; Tyurin, V. S.; Valetsky, P. M.; Van Koten, G. Organometallics 2006, 25, 154. (d) Huang, L.; Wang, A.; Ang, T.P.; Tan, J.; Wong, P. K. Catal. Lett. 2006, 112, 219. (e) Saffarzadeh-Matin, S.; Kerton, F. M.; Lynam, J. M.; Rayner, C. M. Green Chem. 2006, 8, 965. (f) Ren, N.; Yang, Y.-H.; Zhang, Y.-H.; Wang, Q.-R.; Tang, Y. J. Cat. 2007, 246, 215. (g) Zhang, Z.; Wang, Z. J. Org. Chem. 2006, 71, 7485. (h) Safavi, A.; Maleki, N.; Iranpooor, N., Firouzabadi, H.; Banazadeh, A. R.; Azadi, R.; Sedaghati, F. Chem. Commun. 2008, 6155. (i) Budarin, V.L.; Clark, J.H.; Luque, R.; Macquarri, D.J.; White R. J. ; Green Chem. 2008, 10, 382. (j) Demel, J.; Park, S-E.; Cejka, J.; Stepnicka, P. Catal. Today 2008, 132, 63.

4. (a) Vallribera, A.; Molins, E. Aerogel supported nanoparticles in catalysis in Nanoparticles and Catalysis, Wiley-VCH, 2008. (b) Martínez, S.; Vallribera, A.; Cotet, C. L.; Popovici, M.; Martín, L.; Roig A.; Moreno-Mañas, M.; Molins, E. New J. Chem. 2005, 29, 1342. (c) Martínez, S.; Moreno-Mañas, M.; Vallribera, A.; Schubert, U.; Roig, A.; Molins, E. New J. Chem. 2006, 30, 1093.

5. Niembro, S.; Vallribera, A.; Moreno-Mañas, M. New J. Chem. 2008, 32, 94.

6. Bernini, R.; Cacchi, S.; Fabrizi, G.; Forte, G.; Niembro, S.; Petrucci, F.; Pleixats, R.; Prastaro, A.; Sebastián, R. M.; Soler, R.; Tristany, M.; Vallribera, A. Org. Lett. 2008, 10, 561.

7. Niembro, S.; Shafir, A.; Vallribera, A.; Alibés, R. Org. Lett. 2008, 10, 3215.

8. (a) Corriu, R. J. P. Eur. J. Inorg. Chem. 2001, 1109, (b) Corriu, R. J. P. Angew. Chem. Int. Ed. 2000, 39, 1376, (c) Loy, D. A.; Shea, K. J. Chem Rev. 1995, 95, 1431, (d) Loy, D. A.; Shea, K. J. Chem. Mater. 2001, 13, 3306.

9. Gulevskaya, A. V.; Maes, B. U. W.; Meyers, C. Synlett, 2007, 71.

10. Sharp. K. G.; Scherer, G. W. J. Sol-Gel Sci. 1997, 8, 165.

11. (a) Scharp. K. G. Adv. Mater. 1998, 10, 1243. (b) Michalczyk, M. J.; Sharp, K. G.; Stewart, C. W. U. S. Patent 5726 247, 1998. 
12. For some reviews see: (a) Heck, R. F. Acc. Chem. Res. 1979, 12, 146. (b) Heck, R. F. Org. React. 1982, 27, 345 (c) Kalinin, V. N. Synthesis 1992, 413. (d) de Meijere A.; Meyer, F. E. Angew. Chem. Int. Ed. Engl. 1994, 33, 2379. (e) Cabri, W.; Candiani I. Acc. Chem. Res. 1995, 28, 2. (f) Beletskaya, I. P.; Cheprakov, A. V. Chem. Rev. 2000, 100, 3009.

13. Katritzky, A. R.; Lam, J. N.; Faid-Allah, H. M. Talanta, 1991, 38, 535. 